\title{
Illegality and insecurity
}


Gerben Nooteboom - 9789004253681

Downloaded from Brill.come4/26/2023 12:20:42AM via free access 


\section{GERBEN NOOTEBOOM \\ Out of wedlock}

\section{Migrant-police partnerships in East Kalimantan}

In 2002, two Dutch inspection officers working on a joint Indonesian-Dutch operation against illegal trading in endangered species travelled to a large provincial capital in Indonesia. Shortly after arriving, they discovered that a brand new camera had been stolen from their luggage at the airport. In a meeting with the city police chief (kapolres), the Dutch officer complained about the incident. He said he had just bought the camera in Singapore for about $€ 1,000$. 'Hold on', said the police chief. 'Let's see what we can do.' The next morning, when the team met again, the camera lay undamaged on the chief's desk. 'It has been returned', the kapolres announced triumphantly. 'We know how to access their networks.' ${ }^{1}$

This incident illustrates how close the ties can be between police and criminal organizations in Indonesia. The police often know the thieves and pickpockets who are active in their district and can pinpoint the areas in which they operate. Sometimes they even know the pickpockets personally. To some extent, the police treat criminal practices as acceptable or legitimate. As one police officer put it, criminals are allowed to operate 'as long as they do not bother the people too much and do not target government officials, military officials and officers and their families'. ${ }^{2}$ According to researchers at two Yogyakarta universities, pickpocketing gangs in most Javanese towns use the 'cupboard' method. ${ }^{3}$ They store the wallets or mobile phones they steal in a special cupboard. If, after four days, no police officer, soldier or high-ranking official has claimed any of the stolen items, the cupboard is opened and the items are sold.

Other ties between the police and the underworld are more serious. Researchers and journalists have found evidence of direct involvement of police officers in criminal activities or even killings (Colombijn and

\footnotetext{
1 Personal communication with AIVD (Dutch General Intelligence and Security Service) officer, 2003 and 2008.

2 Personal communication with local police officer (polsek) in Samarinda, 2004.

3 Personal communication with Pujo Semedi (Gadjah Mada University, December 2005) and Argo Twikromo (Atma Jaya University, August 2008).
} 
Lindblad 2002:19-20). Today, most reported cases of police illegality involve graft (Montlake 2008; Shari and Einhorn 1998), illegal logging (Casson and Obidzinski 2002), and fraud. Some of these stories are well-documented and are reported in the media. Some are exposed in corruption cases in the courtroom. Others stay hidden or remain the subject of rumours, such as the alleged police involvement in the 'mysterious shootings' (penembakan misterius or petrus) of the early 1980s (Schulte Nordholt 1991; Van der Kroef 1985).

However fragmentary the evidence from around Indonesia may be, it does suggest that police involvement in certain kinds of illegality is common enough to be considered systematic. Significant research into this phenomenon has been possible only in the last decade, since the separation of the police force from the armed forces in 1999. Previously, the police force had always been part of the military and the army had political clout. When the police became independent, they were made responsible for daily security tasks at the local level. This sparked a growing interest in their doings in scholarly journals and in reports from advocacy groups (for example, Amnesty International 2009). From what research has been done, it would appear that the police practices described in this chapter are commonplace in many parts of Indonesia. In the following chapter of this volume, for example, Ian Wilson explains the interaction between police officers and 'protection racketeers' in Jakarta. A report by the International Crisis Group illustrates how politicians and police officers in Bali and Lombok use local militias to levy taxes and keep immigrants off the islands (ICG 2003). The international NGO Global Witness (Paying for protection 2005) has revealed how Freeport pays government security forces to guard its massive copper and gold mine in Papua. Writing for the The Jakarta Post, Apriadi Gunawan provides a detailed account of forced prostitution in the Walet Complex in Bagan Batu, Riau, where the guards are local police officers. On behalf of bar owners, the police provide sex workers with written permission to ply their trade. The same article mentions other brothels in Jakarta and Surabaya where similar practices take place (Gunawan 2006). These are just a few of the many known examples of police involvement in illegal activity.

Such stories raise several questions: How are relationships between the Indonesian police and criminal actors structured? In which types of illegality do these relationships tend to occur? How are the activities legitimized? And how do these relationships affect both the actors involved and the functioning of the state?

These are complex questions. They are difficult to answer as well, for more reasons than one. Not only is police involvement in illegality typically veiled in secrecy, it also tends to be organized at a local level. The aim of this chapter is to provide some insight into the intricacies of state involvement in illegality in Indonesia. This will be achieved by presenting a local case study that lays 
bare hidden practices of police officers and entrepreneurs in East Kalimantan. It may well be that these practices are not restricted to East Kalimantan, but reflect general patterns of illegality in Indonesia as a whole.

This chapter focuses on Madurese migrant entrepreneurs in East Kalimantan and the relationships some of them have with police officers. The analysis presented here is based on the assumption that understanding local circumstances is the key to grasping the relationships between state and illegality in Indonesia. Hence, this chapter does not deal with the Indonesian police in general terms, but focuses instead on the relationship between poor people and the police in a local setting. It provides a view of state and illegality from the bottom up, by offering an account from the perspective of ordinary people's lives. In so doing, this chapter shows how essential illegality often is to poorer people's lives. Without illegality, life would be considerably more difficult for migrants.

This research is based on field work I conducted in East Kalimantan from August 2003 to March 2004, with follow-up visits in 2005, 2007 and 2008. This is a continuation of earlier work on social security, livelihood and risk-taking among Madurese in East Java. ${ }^{4}$ In East Kalimantan, I had originally set out to study Madurese migrants and entrepreneurs and the strategies they employed to make a living under the threat of ethnic violence. Before long, however, I expanded my research focus to include illegal activities and the relationships between migrants and police. I realized that I could only understand the successes, failures, and security problems of Madurese migrant entrepreneurs in East Kalimantan if I had a clear picture of their involvement in underworld activities. As we shall see, my investigations led me to the conclusion that migrants benefit from illegal activities and from their relationships with the police, while police in the East Kalimantan capital of Samarinda have to permit a degree of criminality in order to keep crime under control.

\section{Risky business}

Becoming an entrepreneur is a risky business, especially for poorly educated immigrants of an ethnic group unpopular in the recipient society. Migrant entrepreneurs face numerous obstacles, including a lack of cash or credit, limited access to local information and support networks, and a general ignorance of - and exclusion from - local bureaucratic procedures. They may face discrimination and even threats of ethnic violence. Low-skilled migrants often find themselves excluded from the better paid jobs because these are distributed

4 Nooteboom 2003. Many villagers from this area migrate to East Kalimantan. Chapter 7 of my dissertation describes illegal activities organized by local government officials (village heads), police, army officers, criminals, and gamblers in East Java (Nooteboom 2003:231-4). 
among more established groups. Immigrants are left with few options, aside from doing menial labour, taking up a trade, or going into business.

The disadvantage of being from an ethnic minority group is compensated somewhat by a relative advantage. The minority group's isolation from local society and its governing norms makes it easier for the group's members to engage in profitable, but illicit activities. Hans Dieter Evers (1990:11) describes the traders' dilemma,

[...] of either being integrated into the moral economy of the host society, and consequently subjugated to the pressure of solidarity and sharing, or, on the other hand, of separating from the host society, facing discrimination but also being able to claim debts, to accumulate capital and to conduct business and trade successfully.

Elsewhere, Evers emphasizes how traders tend to minimize risk and maximize trust in inter-ethnic relationships by engaging in many kinds of trading and other relationships (Evers and Schrader 1994; Evers and Mehmet 1994:1). Such considerations may explain why large parts of many immigrant minority groups the world over are entrepreneurs (Raillon 1994) and why they often are successful, especially in the informal sector. The success of immigrant entrepreneurs seems to be the result of a combination of factors: their will (and need) to succeed, their strategic use of ethnic trading networks and inter-ethnic trust, their lack of assimilation, and their willingness to carry out any tasks - no matter how dirty, difficult or unacceptable to others in local society. The last of these factors explains why immigrant entrepreneurs are regularly reported to be involved in illegality.

This general impression also seems to apply to Madurese entrepreneurs in East Kalimantan. In Samarinda, the provincial capital, about 15\% of Madurese migrants own a business or trade. Most of their businesses are small, but they provide jobs to about three-fourths of the estimated 15,000-20,000 Madurese in the city. Some of the migrants who arrived before the 1990s are now well-off and own land, houses, cars, transport businesses, recycling firms, construction companies, gambling dens and brothels. They earned their fortunes in the late 1980s and 1990s when the local economy experienced a logging and mining boom. A number of their businesses seem to occupy a grey area, combining perfectly legal trade with activities such as theft, fraud, illegal logging or land occupation, brothels and gambling dens. Many individual Madurese also work as security guards and assistants for ethnic Chinese businessmen who organize large-scale gambling operations at malls, discotheques and bars. However, widespread violence against Madurese in other parts of Kalimantan from 1997 to 2001 damaged the image and the self-confidence of Madurese 
migrants, making them less attractive as guards for others. ${ }^{5}$ Some Madurese who formerly worked as security guards have started their own businesses; others have retreated into less risky business.

When considered against the backdrop of all illegal economic activity in Samarinda, the Madurese are small players. Very few of them were involved in the massive illegal logging operations of the late 1990s and early 2000s, for instance. Nor did they play a major role in recent cases of corruption linked to government projects, timber and plantation concessions, or the embezzlement of mining royalties. ${ }^{6}$ Although people in Samarinda often brand the Madurese as a criminality-prone group, they are in fact no more involved in illegal activities than other ethnic groups such as the Buginese, Banjarese, Javanese, Torajanese, and Butonese.

According to one local, middle-ranking police officer, the Banjarese and Buginese are currently the most criminally active ethnic groups in Samarinda. Buginese gangs are dominant in protection rackets, the lucrative harbour and market areas, and large-scale illegal trading of all kinds, while Banjarese gangs tend to engage in petty crime such as burglary and pickpocketing. It appears the police look the other way, as long as the crimes committed remain petty and mobs punish some of the perpetrators themselves by public lynching. ${ }^{7}$ In general, the Indonesian population tends not to trust the police and 'people feel that lynching makes the streets safer' (Colombijn 2002:302).

The relationships between small entrepreneurs, illegal activities and the police in Indonesia are the subject of a great deal of speculation but very little actual research. For my own study, I closely followed several East Madurese entrepreneurs and analysed their involvement in both legal and illegal activities. There are several types of illegal activity which the police accept and even benefit from. This does not apply to all crimes, however. There are categories of criminality which the police attempt to stamp out. Among Madurese themselves, there are different views on what is acceptable behaviour. Moreover, it appears that police officers often collaborate with the Madurese or even help them carry out some illegal activities. Before discussing these situations in detail, I will first elaborate on the research methodology I used and then sketch the background and structure of Madurese migration and entrepreneurship in East Kalimantan.

\footnotetext{
5 For analysis of anti-Madurese violence elsewhere in Kalimantan see Schiller and Garang 2002; Davidson and Kammen 2002; Peluso 2006; Peluso and Harwell 2001; Van Klinken 2002. I have discussed the loss of selfesteem and its impact elsewhere: De Jonge and Nooteboom 2006; Nooteboom 2005.

$6 \quad$ For illegal logging in East Kalimantan, see Casson and Obidzinski 2002.

7 In his discussion of public lynching across the country, Freek Colombijn (2002) describes several mob lynchings which occur while the police stand idly by. He concludes: 'The response of the police to mob justice is in general half-hearted [...] After the fact, however, the police accept the lynching as it is. They never try to investigate the matter' (Colombijn 2002:319). See also Welsh 2008.
} 


\section{Researching illegality}

For obvious reasons, studying relationships between police and migrants in the context of illegality is not easy. By nature, illegality concerns covert activities, sensitive topics, uneasy relationships, distrust, and a shared interest in secrecy for all actors involved. Migrant groups and police networks are both difficult to gain access to. Information and locations are often blocked by gatekeepers - these may be gang leaders or even police officers - who tend to prohibit activities, deny access, or frustrate interviews and observations. Outsiders, including researchers, represent a potential threat. Silence is essential to the continuation of illegal activities.

Information on illegal activities is not limited to leaders though. Often there are many people who are aware of such activities and who possess crucial information about them. This is because the activities usually depend on social networks and may involve huge numbers of actors. These actors seldom know all the facts, but they are able to reveal part of the illegal practices they are involved in. There are anthropological research methods suitable for approaching such people, gaining access to their networks and gathering insights without directly mentioning illegality as a research theme.

The study of illegality in daily life requires an unobtrusive and indirect approach. I used a bottom-up method in which I gathered information about various economic activities by Madurese migrants in East Kalimantan, embedding it in a larger study on livelihood and social security styles. ${ }^{8}$ By studying the migrants' livelihood activities, insecurities, and social networks, it proved feasible also to study their illegal activities and their relationships with police officers. This method provided access to the perspective of the Madurese migrants themselves, rather than that of police officers. In order to conduct this research, I had to develop close contacts with ordinary Madurese workers, migrants and entrepreneurs. Many were willing to tell me about their livelihood activities - including the less legal ones - and to show me around behind the scenes at markets, wedding ceremonies and bars, or take me to cockfights, illegal brothels, and gambling dens.

I studied Madurese settlers in three clearly demarcated clusters of economic activity: brick making, stone cutting, and vegetable growing. The first two sectors are dominated by Madurese from Bangkalan (West Madura) and Sampang (Central Madura) respectively. Most brick makers work on the outskirts of the city of Samarinda, while stone cutters can be found in the hills of Batu Putih and Batu Besaung, west and north of the city. In the vegetable growing area of Lempake, to the northeast of Samarinda, Madurese-speaking migrants from Malang (East Java) dominate.

8 For the wider study see Nooteboom 2008. 
Within these clusters of economic activity, which were relatively homogeneous with respect to place, descent, social class, and ethnic identity, I observed a wide variety of ways in which people tried to make a living, interpreted ethnic violence, maintained contacts with other ethnic groups, and strove for business success and social advancement. My research comprised three phases with a progressively narrowing scope. In the first phase, I mapped out the various economic activities, locations and backgrounds of Madurese migrants. To conclude this phase, I selected three sectors dominated by Madurese. In the second phase, I conducted semi-structured interviews with questions on livelihood constitution, livelihood patterns, incomes, remittances, social security, perceptions of crisis and violence, relationships with state officials (including police officers) and inter-ethnic relationships. In the last phase, I revisited a dozen families on a weekly basis to conduct lengthy interviews and construct life histories; I again revisited some of these families in 2005, 2007 and 2008.

During the second phase, I became interested in the illegal activities people were involved in. I made further inquiries among brick makers and workers in the quarries and brothels and carried out participant observation of cockfights, gambling, and brick making activities. Although it was nearly impossible to interview police officers, officials from the State Intelligence Agency (Badan Intelijen Negara, BIN), or politicians, I managed to conduct a few informal interviews with such people without revealing the purpose of this study. It is mainly for this reason that this chapter adopts a bottom-up perspective on state and illegality, looking at interactions through the eyes of Madurese migrants.

\section{The Madurese in Samarinda}

Most Madurese in Samarinda are still economically unsuccessful and have not escaped poverty. They are poorly educated though famous for being hard workers. As a result, they are in demand in sectors where hard physical labour is required, such as transport and construction. Many porters at the harbour and the markets are Madurese, as are many road workers, builders, garbage collectors, stone cutters, and brick makers. Others work as security guards, carpenters, owners of repair shops and hairdressers. The banana trade and sate sector are dominated by Madurese, as well as most of the canteens at the main university campus. In general, Madurese migrants occupy the lower strata of East Kalimantan society.

It is widely claimed that Madurese migrants in Kalimantan tend to spatially isolate themselves from other groups (Peluso and Harwell 2001:103). In this, however, they do not differ from other ethnic groups who also prefer to 
live close together. In East Kalimantan, Madurese tend to settle in close proximity to each other, often in relation to their occupation or village of origin. In Samarinda, they live in old districts close to the harbour and the city markets. Clusters of brick makers from rural Bangkalan can be found on the outskirts of the city on otherwise unused lands. Temporary labourers who work in road construction and on building sites mostly originate from eastern Java and Sampang in Madura; they tend to live in barracks or deserted houses scattered throughout the city. Migrants who stay for long periods are more likely to live in mixed communities and interact with other ethnic groups such as the Javanese, Banjarese, Kutai Malay and Butonese. However, relationships between Madurese and Buginese, the second largest ethnic group in East Kalimantan, have long been tense. Traditionally, contacts with the indigenous Dayak are relatively cordial, although they became tense following violent attacks on Madurese by Dayak in West and Central Kalimantan.

During the colonial era, most Madurese in this province were employed as unskilled labourers on plantations and in the mining and oil industries around Balikpapan. ${ }^{9}$ This situation remained basically unchanged until the late 1970s. From that time onwards, migrants have mainly been engaged in road construction, recycling (scrap metal and tires), small trade, brick making, logging, and the building and transportation sectors. Some have become very successful, acquiring heavy machinery and large trucks. A small number have also become involved in illegal activities.

Madurese in Samarinda live simply, save money to invest, marry young, and help each other. They also provide accommodation to newcomers many of whom are relatives or people from their villages of origin - and help them to find jobs. They tend not to seek an education; the few Madurese in East Kalimantan who have graduated from university have difficulty finding suitable jobs. As a result, there are almost no Madurese in the government bureaucracy or higher ranks of the police in East Kalimantan. According to Hendro (2001:72), 'the majority can neither read nor write', with illiteracy rates of $40 \%$ to $50 \%$ for male workers and even higher percentages for women. Madurese parents often keep their children home from school and expect them to help the family make a living. Religious knowledge, though, is highly valued. In East Kalimantan, several Madurese pesantren, religious boarding schools, have been founded. Well-to-do Madurese often send their children to pesantren in Madura and Eastern Java. Some have made hajj.

The Madurese in East Kalimantan are not a homogenous group. They make a distinction between Madurese from Bangkalan, Sampang, Pamekasan and Sumenep. These groups speak different dialects, follow different re-

9 During the Japanese occupation an unknown number of forced labourers (romusha) were recruited from Madura to work on plantations and infrastructural projects in Kalimantan. 
ligious leaders (kiai) and emphasize different cultural traits. For instance, Sumenep Madurese are said to be more refined than those from Pamakasan, whereas those from Sampang are generally perceived by others and themselves as being the least refined of all, as unreliable troublemakers.

According to many Dayak, Malay, Buginese and Banjarese sources, the Madurese have done little to adapt to their new social environment. Instead of accommodating other groups, they are said to look down on others. Their behaviour is routinely described as arrogant, short-tempered, boorishly masculine, rude, uncivilized, unfair, avaricious and vengeful. These are all characterizations and stereotypes that have been applied to the Madurese since colonial times. In times of crisis, such prejudices are infused with additional meaning because they are sometimes used to justify violence against the Madurese (De Jonge 1995). Many Madurese who were born in Kalimantan blame this negative image on newcomers, who they claim do not know how to behave, and on thugs (preman) who belong to criminal gangs involved in illegal logging, running brothels and gambling dens, and smuggling consumer goods. According to these more established Madurese, the newcomers cast a shadow over the whole Madurese community.

\section{Relationships with police officers}

Whenever a theft takes place in Samarinda, local Madurese are the usual suspects. This is just one effect of negative stereotyping. The negative image also makes it hard for Madurese to establish new businesses or to expand existing ones. However, their lowly status as a migrant underclass also puts them at an advantage in the sense that they have more room to manoeuvre in illegal sectors of the economy. To protect their position, many Madurese entrepreneurs maintain regular contacts with police officers, who protect their businesses and informally facilitate illegal activities.

For the police, such arrangements with marginalized Madurese entrepreneurs are also beneficial because this is how the police gain access to lucrative illegal activities. Moreover, the entrepreneurs are willing to do the 'dirty' jobs which the police cannot do themselves. Examples include running semi-legal stone quarries and excavations of clay for the brick industry, running brothels, organizing cockfights and other forms of gambling, running protection rackets, and even engaging in petty crime such as pickpocketing, organizing pyramid schemes, and stealing. For each activity, the participants need to pay regular premiums to the police officers who routinely visit them. These premiums can vary widely: 5-20\% of the earnings for unlicensed brick, stone and transport businesses, over $50 \%$ for most illegal and criminal activities such as running brothels or organizing large-scale gambling. According to some 
Madurese informants, police officers tend to keep quiet about their involvement in smaller-scale activities. They usually do not tell their colleagues for fear of putting their own profits in jeopardy.

Moreover, their position as members of a feared and reviled minority group makes Madurese ideal candidates to be hired by security personnel for dirty work involving intimidation and competition between political rivals or interest groups. Active involvement by Madurese in intimidation of business or political groups has declined in recent years. Many Madurese preman used to be involved in such activity in the 1980s and 1990s. However, the widespread violence against Madurese in West and Central Kalimantan that began in 1997 made them more politically vulnerable in East Kalimantan and diminished their role as henchmen, in gang conflicts and in protection rackets. Many Madurese are, however, still employed as security guards in gambling dens, bars, discotheques, and brothels. Good relationships with the police are essential to maintaining these positions; if relations with the police are poor, the Madurese are the first to be punished.

By not engaging directly in illegal activities, the police remain free of direct responsibility while enjoying the profits. The ordinary police officers who collect the proceeds from petty crime in turn pay part of these proceeds as tribute to their superiors within the police apparatus. The Madurese who engage in these mutually beneficial relationships with the police end up, by visibly participating in illegality, reinforcing the negative public image of the Madurese as a group.

\section{Communal norms}

Within their own community, the Madurese are relatively intolerant of illegal activity. On the contrary; most Madurese take pride in their community and are religiously orthodox. They clearly distinguish between licit and illicit behaviour in business. Drinking, prostitution, and gambling are considered unacceptable, for instance. Involving Madurese women in prostitution, no matter how bad their reputation may be, is perceived as shameful to the whole community and is severely punished. ${ }^{10}$

Crimes such as stealing and cheating customers (by not repaying debts or by supplying a lower quantity or quality of goods than paid for, for example) are considered less serious, as long as the aggrieved party is not Madurese

\footnotetext{
10 Remarkably, Madurese-speaking prostitutes from the island of Java, especially from the areas of Pasuruan, Lumayang, Besuki, Bondowoso, Jember and Sitobondo, are permitted to work in Madurese-run brothels in East Kalimantan. They are generally considered to be outsiders by members of the local Madurese community who come from the island of Madura. A quick survey among brothel owners indicates that these Maduresespeaking women from East Java comprise the largest ethnic group among prostitutes in Samarinda.
} 
and nobody gets hurt. Many Madurese men retell stories of their own feats of cheating and stealing over and over again; this enhances their status as 'daredevils' and demonstrates strength and cleverness. Nevertheless, no matter how much money is earned from such activities, the profit is generally perceived as unclean or forbidden (haram) and cannot be used for religious purposes such as paying Islamic tax (zakat), donating funds for the building of mosques, or - according to some purists - spending on household needs. Many Madurese say such profits are hot money (uang panas), in other words: easy come, easy go. Some women told me they would not knowingly accept haram money from their husbands, even if they badly needed it for food and other basic needs. As a result, men often spend the money on clothes, food, or presents, and give their wives these goods rather than money.

At Idul Fitri, the festivities that follow Ramadan, I witnessed the youngest son of Hajji Yusuf visiting his father's home. ${ }^{11}$ Members of the family had avoided talking about this son in most of my conversations with them, as he was a habitual gambler and working as a game organizer and security guard for a Chinese businessman in Balikpapan. I never got a complete picture of his activities because his father and brothers did not want to talk about him. During his visit, he offered his father some sorely-needed Rp 50,000 notes. But his father refused the money and ignored his son completely, which I thought was quite embarrassing for the son. Hajji Yusuf later told me he had not wanted to accept money that was probably earned through haram activities. Later still, when I was getting ready to leave, Yusuf's wife proudly showed me the money her son had given her. She had accepted it with gratitude. Hajji Yusuf will probably never know how his wife paid for food that month.

Illegality appears first and foremost to be men's business, but women often condone their husbands' activities and create a conducive environment. Wives are often prominent in money laundering, in sending profits to and investing in Madura, in managing the girls in the brothels, or in establishing legitimate businesses as a cover for illegality. They often remain silent when their husbands lose large sums of money gambling or from fines for illegal activities without police protection. The wives of men involved in illegality often secretly save gold or cash for difficult times, act as moneylenders to other Madurese, or invest in legitimate businesses such as local shops, trades, food stalls (warung), or trucks. Some of these wives buy cattle, land or houses in Madura. At the same time, women often try to coax their husbands away from criminal activities and sometimes play a crucial role in persuading them to go straight.

After achieving success illegally in their younger years, many men reach a turning point when they become older, typically in their mid-thirties or early

11 Hajji Yusuf is a close friend of Hajji Romli, who is introduced later in this chapter. Hajji Yusuf worked for Hajji Romli before they travelled to Mecca. 
forties. They come to see the dirty and dangerous work they are involved in as emotionally exhausting or unsustainable. Gradually, or sometimes abruptly, men abandon their criminal activities and invest their money in legitimate business activities. This change often goes hand in hand with a turn towards religiousness, which is usually seen as a kind of repentance and is sometimes sealed by a pilgrimage to Mecca. Such a transformation is usually celebrated by Madurese friends and relatives, who do not view this as a sign of weakness or decline but as a move towards a better life. In a way, leading a 'life of $\sin ^{\prime}$ in youth is almost a precondition for becoming a real man and a genuine Muslim later. Most entrepreneurs pay a high price for their conversion, however. Their legitimate enterprises quickly lose customers and resources, and household income drops accordingly. A certain degree of illegality facilitates economic success. Therefore, good relations with the police are essential even to those who run a simple business.

\section{Three life stories}

For the remainder of this chapter, I will illustrate the structure of relationships between Madurese entrepreneurs and police based on three examples. I will discuss them in ascending order of intimacy with the police and with illegality. The three Madurese who I will refer to by the pseudonyms Sudi, Romli, and Tamim are all self-made men. We begin with 'Sudi', a brick maker who has no proper deed for the land he uses. He receives protection from a police officer in return for bricks or money. His good relations with the police, although costly, ensure the survival of his enterprise. They spare Sudi time-consuming red tape and legitimize his excavation of fertile topsoil. Moreover, his connections with the police protect him from competing land claims and hostility from his neighbours.

My next example is 'Romli', a trader and transporter of building materials who formerly made a living from smuggling, theft and extortion. After ceasing these activities under police pressure, Romli fell on hard times. With the help of his wife and brother-in-law, he succeeded in transforming himself from a feared gang leader into a respected community leader. Due to his close contacts with the police, he is often able to negotiate on behalf of Madurese who have been jailed for petty crimes. He can get their fines reduced or even secure their release from police custody. In return, Romli has to act as a police informant in cases of murder or ethnic violence.

My final example is 'Tagil', who offers us a glimpse into the double life led by many criminals in Indonesia. He is a gambling boss and pimp who runs his own illegal activities, but is also an instrument in the hands of the police force. 
I met Sudi several times in 2003 and 2004. I observed him at his brick kiln, situated on a back road to Bayur. Whether he was taking a break, overseeing his employees, or firing bricks himself, he was always prepared to talk to me at length. He openly shared his life story with me. Sudi arrived in East Kalimantan from Madura in the mid-1980s. Within five years he had become a successful organizer of cockfights and other betting events. He was feared for his aggressiveness and bad temper. Many people saw him as one of the most daring young Madurese 'madmen' roaming Samarinda in the mid1990s. 'Everyone was afraid of $\mathrm{me}^{\prime}$, he told me during one of our conversations. 'I could beat anyone. Be it in fighting, drinking or motorbike racing, I always wanted to win. There were times when I had loads of money, but sometimes I lost large amounts and did not come home for days. In the end, I had run up a debt of Rp 26 million.' In one of our interviews I ventured to ask his wife, who did not take part in our conversation but listened closely to our every word, whether she had been angry about his behaviour or tried to prevent him from gambling. 'Angry? What do you think? Of course I was angry at him. But, you know, it was better to remain silent with this man. I had two young children. If you get mad with hot-headed people like him, they get even meaner and rougher. It's better to be careful.' Sudi nods. 'That's what I was like. When I came home late at night and my wife didn't open the door fast enough, I would kick it in.'

After a violent fight with Buginese thugs, one of whom was reportedly severely wounded or killed, Sudi ended up in a police cell. ${ }^{12}$ One of his maternal uncles in East Kalimantan, Saïd, knew the right people in the police force and managed to bribe him free on condition that Sudi would never again engage in crime. Saïd demanded that Sudi give up his life of drinking, gambling, and consorting with prostitutes, and offered him a job as foreman in his brick making enterprise. Saïd's close ties with the police protected Sudi from the revenge of the Buginese men. This marked the start of a new kind of life for Sudi.

Nine years later, Saïd sold some of his possessions in Kalimantan and made a pilgrimage to Mecca. When he returned, he went bankrupt, due to his own overspending and embezzlement by his business partner. This meant Sudi was out of a job. He started to gamble again. Over the course of a few months he lost millions of rupiah. In the hope of changing his luck, he borrowed money from a friend and bought a cheap brick kiln in Bayur. The kiln had previously belonged to a Madurese who had been accused of

\footnotetext{
12 Sudi did not tell me exactly what happened to these Buginese men, whom he called 'wounded thugs'. I got some information about them from others, but the accounts were second hand and sometimes ambiguous. Some said one or more Buginese thugs had been killed, while others said some had been severely wounded but none killed.
} 
theft and killed by an angry mob. To obtain clay, Sudi rented land from villagers with the help of a policeman, a friend of his uncle Saïd's. The policeman paid a few of the villagers money and ordered them to cease hostilities against Madurese. Around the same time that Sudi was producing his first bricks, it became clear that there were several land claims on the plot where the kiln was located and where Sudi obtained his clay. Villagers from two neighbouring villages claimed the plot was their communal land and protested the commercial excavation of the soil. Moreover, they did not want any Madurese living nearby.

Sudi called on the help of the policeman. The policeman visited the area often and word of his friendship with Sudi spread fast. Regular sightings of him at Sudi's kiln discouraged villagers from protesting. According to Sudi, the policeman also talked to the village elders. His relations with the neighbours have settled down. 'I even visited their mosque and donated 4,000 bricks for its renovation. But I do not fully trust them. I need my friend the police officer. He also helped me when some Buginese men were hunting for me in an attempt to reclaim a gambling debt. My friend [the police officer] brought them some of my money and told them to go away. They never returned.'

The policeman's protection comes at a price, however. From the beginning of their cooperation, the officer asked to be paid $5 \%$ of all the bricks Sudi produced. In Sudi's first year, when bricks were expensive and his production was still low, the policeman took 17,000 bricks whose total value was nearly $\operatorname{Rp} 6$ million. 'Rumour had it he was building a house for himself.' Later, when the price of bricks fell, the police officer wanted to be paid $\mathrm{Rp} 500,000$ for every 100,000 bricks produced. Currently, Sudi has a large business. He produces some 250,000-300,000 bricks per year and employs eight to ten people. Yet the cooperation continues. When the bricks are fired, about five or six times a year, the policeman visits Sudi and asks for payment. 'I do not know where he lives, but if he comes, I give him Rp 100,000 or more if he keeps on asking. He's actually poor', Sudi explains. 'He has to give most of his money to his superiors.'

In the course of my study of Madurese livelihoods in East Kalimantan, I encountered several enterprises such as Sudi's. The entrepreneurs I met got access to land or even land titles thanks to their close ties with the police. Some of them received direct police protection during land conflicts, hostilities or problems with creditors. In seven cases out of the 118 in my sample, entrepreneurs told me explicitly, and without being prompted, about their relationships with the police, including information about the payments they made and the percentages taken. In another five cases, businesspeople informed me about similar relationships, but in less detail. ${ }^{13}$ Two-thirds of these

13 I could not inquire directly about relationships with the police in interviews I conducted. In some cases I thought discussing these relationships would be deemed inappropriate, and in some of my earlier interviews I had not yet begun to focus on this topic. 
twelve cases were brick making enterprises. Most of the others were remote quarries where stones are cut for road construction.

Most quarry labourers are from Sampang and prefer, for one reason or another, to work in these remote locations. Some of them have fled from ethnic violence in West and Central Kalimantan, while others are migrants with dubious legal status because they lack local identity permits (Kartu Tenaga Kerja, KTP). Some have problems such as unpaid debts, criminal charges or accusations of extra-marital relationships hanging over their heads. Many told me they were working in such a remote place because they had received threats of revenge murder (carok). The quarries are located in largely uninhabited, hilly areas some 5-20 kilometres from the city. In the quarries, individual police officers provide protection in return for a percentage of the earnings for all truckloads of stone delivered. They come to visit every week and sometimes bring basic supplies such as drinking water, salt, soap or rice. In the quarries, policemen are paid commissions of up to $15 \%$ of the value of the stone produced. In general, this is higher than the percentages paid at the brick kilns. I did not hear of the police receiving any more than $5 \%$ in the brick industry. Percentages at the quarries are probably higher because people there are more vulnerable and the money covers personal as well as business protection.

It is money well spent. In Sudi's case, the premiums have protected the enterprise against legal claims by neighbouring villagers and ended his troubles with old enemies. Unlike earlier situations in which he paid police officers who turned out to be unreliable or incapable of helping out, this relationship has yielded results. It has ensured continued access to resources and the sustainability of the family business. Five to $15 \%$ is a small price to pay for success, certainly for a migrant. But premiums depend on the kind of business, the level of illegality, and the tolerance of higher-ranking police officers. Sometimes the police want more control and make greater demands.

\section{Conflicting loyalties: Romli}

Hajji Romli lives on one of the main roads connecting Samarinda to the hinterland of East Kalimantan. His white peci hat and grey beard make it difficult to guess his age. He stares intently with his black eyes. He speaks quickly and asks direct questions. He and his wife run a successful distribution centre stocked with building materials such as sand, bricks, stone, cement, and timber. Since 2006, he has also operated as a subcontractor for basic construction work in large building projects. On these projects, Romli delivers the supplies and carries out the groundwork, lays the foundations and sometimes completes the construction of brick walls, sewage systems and roads. Other 
subcontractors take care of the wood, iron and roof work and other refined tasks. Romli also tenders as the main contractor for smaller projects, such as public buildings, small roads and drainage systems. The trade and contracting business are basically his, but his wife organizes the transportation. She owns four trucks and an excavator. Romli usually uses two of these trucks for construction orders. 'I only take large orders such as houses, blocks or shops, otherwise I do not make a profit. If the work is big, I send for more labourers from Java and use trucks that belong to fellow Madurese businesses.'

As my research progressed, I slowly realized how important Romli was as an informal leader in the Madurese community and a broker in relations with the police. He negotiates bribes when Madurese are arrested for petty crimes or taken into custody after traffic accidents. He supports Madurese who occupy land claimed by others, and he mediates in property conflicts. He was also involved in peace negotiations during ethnic tensions in 2005 and 2007.14 In return for his loyalty to East Kalimantan's elites, he has been granted excavation concessions in the rocky hills of Batu Besaung and is allowed to bid for construction projects. Whenever ethnic tensions arise in Samarinda and surroundings, Romli is called upon by the town mayor, members of the East Kalimantan parliament, the chief of police or a military commander to persuade the Madurese to refrain from violence. He is regarded as influential among the Madurese and loyal to the interests of the ruling elites who set great store by stability. ${ }^{15}$ During our conversations, fellow Madurese were continuously visiting his house to ask for advice, borrow money, or discuss matters of political interest. The nearly constant beeping and ringing of his several cell phones illustrated the extent of his social network.

In the 1970s and 1980s, Romli was one of Samarinda's most notorious gang leaders and gamblers. His wife saved part of the profits and at the end of the 1980s she bought a truck to rent out and to use for the transport of construction materials. In those years, Romli was involved in petty theft as well as swindles that involved receiving payment for goods that were never delivered and loans that were never paid back. He also organized betting fraud on a large scale. However, he is quick to point out that he 'did not steal from our friends and fellow Madurese'. He is also said to have been involved in several killings of Buginese rivals, but he always skirted this issue in our discussions. The rumours about him added to his reputation for toughness.

\footnotetext{
14 The 2005 negotiations, which were initiated by East Kalimantan's security forces, are briefly described in De Jonge and Nooteboom 2006:470-1. At the end of 2005 tensions rose between Dayak and Madurese in Samarinda due to the stabbing of the son of a Dayak adat leader and the deaths of two Madurese. Romli was invited to the security meetings and was able to calm Madurese groups who were calling for revenge. This increased his political influence and improved his contacts with high-ranking security officials.

15 See De Jonge and Nooteboom 2006 and Van Klinken 2002 for a description of these elite interests in East Kalimantan.
} 
To this day, Madurese enjoy a great deal of respect from their community if they killed Buginese gang leaders in those years. 'In the 1980s, it was not safe in Samarinda', Hajji Romli recalls quietly. But, as he explains, he reached a turning point.

I lived a bad life and almost daily we had fights at the market. I was clever enough never to be caught and I had many friends in the police who informed me when activities were getting too hot. On a certain day, a high-ranking police officer came to my house and asked me to stop stealing and to help them fight criminality. If I rejected [their offer], I would be the first Madurese to be taken to prison, they said. I could not do anything but obey. Moreover, deep inside of me, I already knew the things I was doing were wrong. I longed to live a better life.

At this point, Romli stepped down as a gang leader and stopped stealing.

I also did not fight anymore, but rather tried to prevent my people from gambling. [...] I was regularly asked by police officers to 'convert' certain hotheads and criminals who were fighting and causing trouble at the market. I had to turn them into hardworking people which I did by offering them jobs. The police would allow me to continue to organize gambling, but they asked for a cut of the profit.

Only after Romli made a pilgrimage to Mecca did he stop gambling. As Hajji Yusuf told me, Hajji Romli had persuaded him to go to Mecca. 'He even paid part of my way', Yusuf said. 'But we could not quit our habits at first. During the long wait at the airport, we continued gambling for money. Only after our return from the holy land did we stop gambling for money. Now we use penalties.'

In the meantime, his wife had purchased a second truck. Thanks to increasing demand for construction materials, the business expanded and Romli offered jobs to several former members of his gang. Not everyone accepted his decision to go straight. Many of his former followers continued their criminal activities, while others joined different gangs or started businesses of their own. But, said Romli, 'the majority remained loyal to me and after some time, I was able to persuade them to start working for me.' Eventually, the police caught most of the notorious thieves from his group. 'I was a good leader and paid the bribes needed to get them out of prison.' He smiles self-confidently when he says 'this was a good investment. They are now my most loyal workers [...] And, I made some good friends on the police force, which is important.' 


\section{Living dangerously: Tagil}

Tagil's activities are far more dangerous than either Sudi's or Romli's. Tagil is a notorious gambler and a known preman, gang leader, cockfight organizer, and operator of a large bar and brothel in Damanhuri, a prostitution compound on the outskirts of Samarinda. Every season, 30 to 40 women and girls work in this brothel. Most of them come from mainland East Java and $40 \%$ to $60 \%$ of them speak Madurese. But none of them originate from the island of Madura itself, Tagil says. 'We would never permit a Madurese woman to do this. It would cause us shame. She would be killed.'

On Saturdays and Sundays, Tagil organizes cockfights. During these fights, 200-300 people place bets. Most of the gamblers are Madurese and Buginese, but Chinese, Banjarese, Javanese, Dayak, and Butonese also take part. The stakes are high. Chinese and Buginese gamblers in particular place large bets, but Madurese are also known to get involved in this risky level of gambling. On days like Christmas and New Year's, the stakes per fight can soar to the tens of millions of rupiah. However, many spectators also bet smaller amounts ranging from Rp 50,000 to Rp 500,000 on the same fight. The winning better on each fight pays $10 \%$ to Tagil, who in turn pays half of that amount to policemen secretly present in the arena and to higher-ranking police officers. Tagil also takes a cut of the Rp 5,000 entrance fee each spectator has to pay, and from other gambling activities run at the same location, such as Cap Ceki, card and dice games. He also takes a percentage of the concession fees collected from the dozens of ordinary vendors there. The concessions range from $\operatorname{Rp~10,000~a~day~for~a~single~cigarette~seller,~to~} \operatorname{Rp} 50,000$ for a fully equipped food stall offering a range of food and beverages.

With such high stakes, tempers often flare during the cockfights. Things can get so tense that Tagil's gang sometimes needs to restore order. If they are unable to do so, the undercover policemen in the crowd intervene by shooting into the air, arresting people or even randomly shooting some of the fighters in the leg or knee. Tagil then provides payment and mediation to free the arrested gamblers. The fees charged by the police in such a case depend on the status of the person taken into custody and the severity of the offence. Usually they range from Rp 5 million to Rp 15 million. Tagil maintains close ties with the policemen who attend his cockfights. They regularly visit each other's homes, or go out for dinner or drinks. Police officers are said to visit his brothel as well.

On one of my visits, Tagil told me how in the early 1980s he was being sought by the police for the murder of a competing Buginese gang member.

I fled to Madura, to a place where they would never be able to find me. After a few years, a distant relative of mine succeeded, after making large payments, 
to have my name expunged from the police archives. The police officer at that time urged me to never commit murder again and asked if I wanted to help search for criminals who had fled to Java. That's what I did and I still sometimes do. I have become quite good at it. Last year, we chased down a lad in Malang who had raped a girl here and run away to Java.

But Tagil's situation was not as secure as he made it sound. 'The police are asking for more and more money all the time', he complained in confidence later, in 2004. 'The work is dangerous and I cannot do business with the new chief commissioner. I would prefer to retire and move to Java. But I am obliged to keep in touch with them. It's like an arranged marriage.' He hoped to be able to save enough money for a quiet retirement. He told me he was no longer welcome in his home village in Madura. 'They don't want to take my money there anymore. It's haram, they say, unclean.'

A few months after this conversation, in early 2005, Tagil was sent to prison by the new police chief, who accused him of verbally abusing the governor of East Kalimantan. At a meeting with high-ranking officials, Tagil had argued against the closure of the Damanhuri compound during Ramadan and accused the governor of being inconsistent because some other compounds were allowed to remain open. The governor took offence. Other people subsequently told me that Tagil's business had in fact been on the decline for some time, as he had been unable to pay adequate protection money to the police. The new chief of police demanded more money than Tagil was able or willing to pay. Remarkably, the Damanhuri compound did not close during Ramadan that year and Tagil continued to run his racket from his prison cell.

Three months later, Tagil was freed after paying large sums of money. Some people say that his freedom was bought by his uncles, successful entrepreneurs with close ties to the governor. The uncles told me they had merely helped Tagil a bit to succeed in business. 'This is just a family obligation', they said. By 2006, Tagil had gone to work for his uncles in their new business. They had just acquired a badly managed coal concession and started to excavate in areas contested by other claimants, with the backing of influential police officers and politicians. In 2008, Tagil and his uncles actively supported candidates for the provincial elections. One uncle expressed an ambition to enter politics himself. The fact that their business is risky and legally dubious does not prevent them from becoming involved in politics. On the contrary: it makes political ties and protection all the more important. 


\section{Conclusion: Out of wedlock}

Madurese migrant entrepreneurs in East Kalimantan have to overcome numerous obstacles in making their businesses profitable. Brick makers face difficulties acquiring land rights and cheap firewood, transportation entrepreneurs have to contend with a great deal of red tape in obtaining transportation licences, and workers in stone quarries need protection against exploitative middlemen and insecure contracts. Moreover, Madurese migrants are not exactly the most favoured ethnic group in East Kalimantan and sometimes face discrimination and deep-seated hostility. This is not always unjustified, as some Madurese migrants are, or have been, involved in illegal and illicit activities such as cockfights, gambling, theft, gang warfare, and prostitution rackets. Madurese entrepreneurs and preman involved in such illegal activities consider it crucial to maintain good relationships with police officers, generally low-ranking ones, to guarantee protection and the continuity of their operations. They maintain close ties with police officers by way of regular visits and payments of either irregular sums or fixed shares of the profit their business generates.

Obviously, the relationships with Madurese migrants also benefit the police. Aside from generating additional income, these relationships offer the police access to a closed migrant community and help them control that community. ${ }^{16}$ In case of increased ethnic tension or an unacceptable rise in crime, the police call on their contacts with entrepreneurs, preman and ethnic leaders who depend on the police for business success. These same contacts can now be used to help control the Madurese community and fight criminality. These individuals can provide the police with information or utilize their own networks to try to restore calm or curb the activities of particular people. In extreme cases, they may even detain members of the community and hand them over to the police.

These examples show how the interdependence of Madurese entrepreneurs and police officers not only provides direct financial and legal benefits to those involved, but may also serve a higher goal of maintaining security and stability in society. Ironically, this social control is only made possible by allowing criminality and instability to exist at controlled levels.

In the cases of Sudi, Romli and Tagil, it is difficult to pinpoint the exact demarcation line between legality and illegality. There is no need to do so. And it is precisely this grey area which offers Madurese entrepreneurs and the police financial and political room for manoeuvre. The police give migrants protection and in return both sides get a share of the profits generated by illegal activities. At the same time, the police do not tolerate any and all forms of criminality.

16 The strategy is similar to one used by the army's special forces (Kopassus), which frequently recruit criminals to use in counter insurgency campaigns (Liem Soei Liong 2002:202). 
On the contrary, they use their ties with gang leaders to help fight crime. They control the underworld through a combination of taxation and repression. At the same time, they also receive a steady flow of income from illegal activities.

Bribes, commissions and profits from illegal activities lower the transaction costs for disadvantaged groups who have no access to formal, legal economic activity or who lack knowledge of how the legitimate economy works. Without the payments and commissions, it would probably be much more difficult for Madurese to sustain their economic activities. At the same time, the police are also dependent on the entrepreneurs. Police officers in Indonesia are still underpaid, while the people in their social surroundings (friends, family members, neighbours and so on) expect them to maintain a comfortable standard of living and to offer financial help when it is needed. Police officers also face demands for contributions from their superiors on the police force. In short, there is a successful and mutually beneficial 'marriage' between entrepreneurs and the police. The intimacy of the marriage makes it unlikely that there will be a victory anytime soon in Indonesia's repeatedly proclaimed war on corruption.

The marriage is not based on love, however. Just as some marriages involve a certain amount of discretion or even feigned ignorance, the relationship between the police and Madurese businesspeople and criminals in East Kalimantan is equally paradoxical. The police in Samarinda need to turn a blind eye to a certain level of criminality in order to keep criminality in check. By permitting some forms of 'petty' crime such as pickpocketing, stealing, cheating, gambling and prostitution - activities which are detested by the community, but which can be kept within bounds by mob lynchings and public justice - they get access to information about the worst aspects of organized crime (such as killings, gang fights, gang rapes, and car theft) and even ethnic violence. They do this by mingling with networks of criminal groups and engaging in some aspects of their activity.

This world of petty criminality, in East Kalimantan at least, involves collaboration between police and small entrepreneurs and the regular payment of small fees (5-15\% of turnover). The payments ensure the smooth operation of a system based on personal contacts that is an alternative to a properly functioning Weberian taxation and policing system. In this alternate system, the state needs to be involved in illegality in order to control criminality. In Indonesia, state officials have been relatively successful at this. From a citizen's perspective, it is a fairly safe country. In most Indonesian cities, people live without constant fear of being robbed, killed, or raped. And when justice falls short, the police leave the mob enough space to take revenge. A 5 to 15\% premium is a much lower price for security than the taxes most people pay in countries with far less corruption. Clearly, illegality is not destructive per se; it can also help to sustain order in society. 